\title{
Effects of Foreign Trade on the Economic Performance of Industries-Evidence from Wood Processing Industry of Czechia and Slovakia
}

\author{
Andrea Sujová ${ }^{1,2, *}$, L’ubica Simanová ${ }^{1}$, Václav Kupčák ${ }^{2}$, Jarmila Schmidtová ${ }^{3}$ and Adriana Lukáčiková ${ }^{4}$ \\ 1 Department of Economics, Management and Business, Technical University in Zvolen, T. G. Masaryka 24, \\ 96001 Zvolen, Slovakia; lubica.simanova@tuzvo.sk \\ 2 Department of Forest and Wood Products Economics and Policy, Mendel University in Brno, Zemedelská 3, \\ 61300 Brno, Czech Republic; vaclav.kupcak@mendelu.cz \\ 3 Department of Matematics and Descriptive Geometry, Technical University in Zvolen, T. G. Masaryka 24, \\ 96001 Zvolen, Slovakia; jarmila.schmidtova@tuzvo.sk \\ 4 Department of Operations Research and Econometrics, University of Economics in Bratislava, \\ Dolnozemská cesta 1, 85235 Bratislava, Slovakia; adriana.lukacikova@euba.sk \\ * Correspondence: sujova@tuzvo.sk
}

\section{check for} updates

Citation: Sujová, Andrea, L'ubica Simanová, Václav Kupčák, Jarmila Schmidtová, and Adriana

Lukáčiková. 2021. Effects of Foreign Trade on the Economic Performance of Industries-Evidence from Wood Processing Industry of Czechia and Slovakia. Economies 9: 180. https:// doi.org/10.3390/economies9040180

Academic Editors: Luís Carvalho and Joana Costa

Received: 29 October 2021

Accepted: 11 November 2021

Published: 16 November 2021

Publisher's Note: MDPI stays neutral with regard to jurisdictional claims in published maps and institutional affiliations.

Copyright: (c) 2021 by the authors. Licensee MDPI, Basel, Switzerland. This article is an open access article distributed under the terms and conditions of the Creative Commons Attribution (CC BY) license (https:/ / creativecommons.org/licenses/by/ $4.0 /)$.

\begin{abstract}
As was first stressed by the classical economists Adam Smith and David Ricardo, international trade plays a crucial role in the growth process. The paper aims to analyze the influence of foreign trade on economic performance in the wood processing industry (WPI) of Czechia and Slovakia. The multivariate regression method (MLR), assumption tests for MLR models, and Granger causality test were applied to identify association between foreign trade economic performance, and indicators were formed to measure the effects of foreign trade at the industry level. The Granger test revealed the unidirectional causality in the Slovak WPI and bidirectional causality in the Czech WPI. The results revealed that the net export growth has a positive effect on the economic performance of the industry, but only if the growth in imports is lower than in exports. The balanced trade balance indicated no influence of foreign trade on economic performance. The paper contributes to existing knowledge with indicators for evaluation of foreign trade effects on the performance of the industry. The paper also brings new empirical knowledge in trade balance effects on the economic performance of industries.
\end{abstract}

Keywords: contribution of foreign trade; economic performance; Granger causality; multivariate regression; net export; value added rate; wood processing industry

\section{Introduction}

Economic growth belongs among the main goals of each economy and enterprise. There are different indicators used by measuring economic performance and growth at a macroeconomic and a microeconomic level. However, their matter is common, all measures are based on value added. As for performance, at the level of industries (mesoeconomic level), it is going on interconnection of macro and micro level view at economic performance and the principle of value added is kept.

Investigation of factors influencing economic performance and growth has been the subject of much research. Foreign trade belongs among the main sources of economic growth as foreign trade theories by classical economists has revealed. According to Afonso (2001), a trade openness tends to be beneficial for growth, especially openness to the foreign investment supporting innovation rate.

Foreign trade affects the level of a gross domestic product of the country as well as the performance of industries and enterprises. The foreign trade balance is used as a starting point in clarifying the competitive advantages especially at the level of industries and sectors within the economic structure of the country. Competitiveness on the world 
market is the basis for the theory of international trade and economic growth, while in comparison with classical and neoclassical economic theory of international trade, it highlights innovative, realistic sources of trade, and economic development (Bobáková and Hečková 2007).

The relationship between foreign trade and economic growth has been investigated since the origin of foreign trade theories. Antunes (2012) noted that, according to several authors, exports enhance productivity, they bring incentives to pursue technological advancements that can lead to improvement of overall economic performance, and they promote a better allocation of resources through the specialization of goods that have a better comparative advantage. Besides exports, imports as a part of foreign trade balance and their impacts on economic performance should be considered. Although imports have an adverse impact on the trade balance, they can be as important as exports in promoting growth (Awokuse 2007).

Empirical studies focused on the effects of foreign trade on economic performance and growth have been performed in many countries. Most of the studies were based on using statistical or econometric methods and revealed a positive impact of foreign trade on GDP. Measuring the effects of foreign trade on the GDP's growth through designed indicators was provided in several other studies.

A large number of current empirical studies focusing on countries throughout the world indicates that this topic is highly up-to-date. However, almost all studies have been focused on the impacts of international trade on macroeconomic performance and growth. Insufficient attention is paid to such research at the industry level. That is why this paper deals with the assessment of foreign trade effects on economic performance of sectors within the wood processing industry (WPI). The second point is that most empirical studies are based on statistical and econometric methods. An indicators' approach has rarely been used.

Sustainability of economic growth and performance depends on a quality of economic structure of the country and competitiveness of strategic sectors. The wood processing industry in the Slovak and Czech Republics was chosen as an object of investigation for several reasons. The wood processing and wood products manufacturing belongs to traditional sectors of the Slovak and Czech industries. Its development is in a line with the strategy of the European Union that emphasizes economy based on renewable resources. Within currently discussed principles of bioeconomy and circular economy, the wood processing industry belongs among strategic sectors that should be promoted. The second reason for the focus of the study on the wood processing industry is that the industry consists of three sectors creating a value-added chain and thus different valueadded rates: the timber industry, the pulp and paper industry, and the furniture industry. As for the Slovak and Czech wood processing industry, the raw wood material belongs among abundant specific inputs. The utilization of wood in the domestic wood processing chain and export of wood-based products should bring a positive effect on economic performance of the industry. Therefore, it is worthy to search the effects of international trade on economy of WPI.

This paper aims to analyze the effects of foreign trade on economic performance of the WPI in the Czech and Slovak republics based not only on a statistical and econometric analyses, but also on the designed indicators.

Statistical and econometric methods enable proof of association between economic performance and foreign trade and the direction of the influence. Indicators enable more factual analysis than statistical methods in detection of what changes in export and import have a positive or a negative effect on economic performance.

Analysis by statistical method of multivariate regression revealed the positive effect of imports and negative effect of exports on sales in Slovak WPI and on all economic indicators in the Czech WPI. The assumptions of MLR models were tested for autocorrelation, normality, and linearity. 
ADF test confirmed stationarity of the time series and the Granger test was performed. The test revealed a Granger causality from foreign trade (export and import) to economic performance of the wood processing industry, unidirectional in Slovakia and bidirectional in Czechia.

The contribution of foreign trade indicators revealed that net export growth has a positive effect on the economic performance of WPI if the import increase is lower than the growth in exports.

The paper contributes to existing knowledge with a set of indicators formed for evaluation of foreign trade effects on the economic performance at the industry (mesoeconomic) level. The paper also brings new empirical knowledge in trade balance effects on the economic performance of industry processing abundant input factors.

The rest of the paper is organized as follows: Section 2 presents the literature review. Section 3 presents the methodology of the study. Section 4 presents the results. Section 5 presents verification of research hypotheses and discussion. The last section concludes the paper.

\section{Literature Review}

Economic performance and growth at a macroeconomic level is measured by the gross domestic product (GDP) and the foreign trade balance is one of the components of GDP. This means that trade balance can have a positive or a negative effect on economic performance of the country, industry, or enterprise. GDP is based on a principle of value added as the difference between sales and material inputs costs. Evaluation of enterprise's economic performance is based on financial ratio indicators such as profitability, economic value added, and market value added. The economic performance of the industries can be evaluated by value added, profit, and the ratio indicators based on value added or profit of the industry (Sujová et al. 2015c).

International trade can play an important role in promoting economic growth through the specialization of each country in producing the products in which it has a comparative advantage and by transferring the resources among the different countries (Belloumi and Alshehry 2020).

International specialization has become the order of the day and each nation concentrates on the making of only such products in which it has the maximum comparative advantage and the least comparative cost (Akeem 2011; Ray 2011). According to Ricardo's theory of comparative advantage, a country should specialize in producing and exporting only those goods and services which it can produce more efficiently, that is, at lower opportunity cost than other goods and services, which it should import (Enu et al. 2013). The Heckscher-Ohlin trade theory claims that countries will tend to have comparative advantages in producing the goods that use their abundant factors more intensively; for this reason, each country will end up exporting its abundant factor goods in exchange for imported goods that use its scarce factors more intensively (Enu et al. 2013).

According to Nazarczuk et al. (2018), the latest trade models highlight the importance of the reallocation of resources within one sector, as a consequence of changes observed in the trade costs, and the interplay between export performance and business innovation rate.

The advances in international trade theories and growth theories were an inspiration for searching the answer on the question whether foreign trade contributes to economic performance and growth.

Were (2015) provided a comparative analysis among African countries using standard growth regression. A compact review of recent empirical studies on trade openness and growth was provided by Winters and Masters (2013). Although the emphasis in the earlier literature was on exports, it was also confirmed that imports supported economic growth. Several studies were produced in China (Kong et al. 2021; Lin 2000; Sun and Heshmati 2010) applying econometric and non-parametric approaches; the ARDL model. It was found that the growth rate of the volume of trade is positively related to a growth rate of per capita GDP and both international trade volume and trade structure toward high-tech exports 
result in positive effects on China's regional productivity. Trade balance effects on economic growth in European Union countries were analyzed by Blavasciunaite et al. (2020) using the OLS method of multivariate regression analysis. The results indicated the negative impact of a trade balance on economic growth. Makhmutova and Mustafin (2017) analyzed the impact of international trade on economic growth in the largest countries: China, the United States, Russia, and Germany. The countries can be ranked in the order of importance of foreign trade to their economies as follows: Germany, China, the United States, and Russia. An empirical study of the impact of international trade over the period 1971 to 2016 on sustainable development in Saudi Arabia was produced by Belloumi and Alshehry (2020) using the autoregressive distributed lag cointegration framework for annual data. Results in the long-term showed that trade openness has a significant negative impact on economic growth and negatively affects environmental quality.

In their study, Frankel and Romer (1999) found that foreign trade had a positive impact on GDP in the case of 63 countries. Investigation of the effects of export on GDP's growth in 19 developing countries using a vector error correction model was produced by Ghirmay et al. (2001). A long-term relationship between trade openness and GDP's growth was confirmed in 12 investigated countries. Reppas and Christopoulos (2005) found in their study that in Asian and African countries a unidirectional causality from exports to economic growth exists. Unidirectional causality from foreign trade to GDP's growth was also confirmed in the study of Cetin (2016). He used the ARDL cointegration and Johansen multivariate cointegration techniques. Enu et al. (2013) examined the effect of foreign trade on economic growth in Ghana by using a Johansen cointegration analysis. The study found that in the long run, exports had a positive effect on real gross domestic product and as a result, an increase in exports led to an improvement in real gross domestic product. Imports and foreign direct investment had a negative effect on real gross domestic product. The study of Hobbs et al. (2021) investigated the relationships between foreign direct investment, trade, and economic growth in Albania. Econometric tests were used: specifically, the unit root test, the unit root test with a structural break, the Johansen cointegration analysis, the error correction model, and the Granger causality test. Results showed that GDP's growth caused export and foreign direct investment growth in the short term, but not vice versa.

Several indicators have been proposed to assess the impacts of trade balance on the performance at the macro level measured by the growth of GDP. The most used measure is the contribution of foreign trade to economic growth (Breda et al. 2007; Hajnovičová 2008; Coronado et al. 2014). This indicator is based on weights of export and import related to GDP and their difference in the export's and import's growth rates. The second indicator quantifies the effect of export by an input-output analysis. It is based on measuring intensity of domestic production to import, and its calculation includes total exports lowered by induced import to semi consumption. Input-output analysis for the western Balkan economies was provided by Mandras and Salotti (2020) to estimate the output and value-added multipliers of the sectors identified within the context of smart specialization. Estimated multipliers provided an early indication of specific macro-areas on which to focus for potential policy intervention and investments.

Other measures for evaluating the impacts of international trade on economic performance, multipliers of the final use are. According to Lábaj et al. (2008), the multipliers enable quantification of imports induced by exports, domestic production, the consumption of the households and government, the produced added value, and gross capital.

Evaluation of foreign trade effects can be provided through the indicator of the real Terms of Trade (TT), which is most often followed as certain commodity terms of trade given as the rate of the time price index of export to the time price index of import. Another two groups of the term of trade indicators are income terms of trade, which express the absolute value impact of the commodity terms of trade on the physical volume of export and factorial terms of trade, which besides the price development, are also concerned with the productivity of labor development, either in the home country of export only (simple) 
or also abroad (double). A modified indicator of the terms of trade by the rate between imported and exported goods volume is suitable for the evaluation at sectoral level (Jeníček and Krepl 2009).

Development of wood-based industries in European member states is in the national strategies based on the higher utilization of domestic wood resources and finalization of the processing in the country of a wood origin (Sujová et al. 2016). However, the high level of raw wood exports in Czechia and Slovakia is a remaining problem due to its contribution to a trade balance (Kupćák and Pek 2015). Several studies were focused on the evaluation of forest-based sectors' competitiveness, published by Carvalho et al. (2009), Hajdúchová and Hlaváčková (2014), Han et al. (2009), Sujová et al. (2015a), Wanat and Lis (2012), and Zhang et al. (2012). The studies dealing with the competitiveness of wood processing industry in Slovakia and Czechia revealed a comparative advantage at a lower level than the EU average and its declining trend despite the existing potential to contribute to economic growth of the industry. Sustainable development and competitiveness of the wood processing industry is connected with a higher valorization of domestic wood resources.

According to international trade theories, a specialization enables to concentrate on what the country can do best, meaning that the available resources are utilized most profitably (Nazarczuk et al. 2018). The Heckscher-Ohlin trade theory claims that countries may have comparative advantages in producing the goods that use their abundant factors more intensively. In the Slovak and Czech republics, the raw wood material belongs among abundant specific inputs. The utilization of wood in the domestic wood processing chain and export of wood-based products with the highest value added should bring a comparative advantage and a positive effect on economic performance of the industry.

Based on trade theories and results of many empirical studies, it can be assumed that export of wood products will influence the indicators of economic performance of WPI positively, while the import will have an opposite effect. Dynamics of a foreign trade balance and coexistence of import and export flows should be taking into account by considering the effects of foreign trade on economic performance. This was the basis for the research hypotheses statements.

\section{Methodology}

A survey of existing literature and empirical research results dealing with the relationship between foreign trade and economic performance and its growth was the first step of the objectives and methodology of this paper. The object of the analysis is the wood processing industry. A characteristic feature of the WPI is the processing of raw wood and wood products manufacturing at various stages of finalization. Within the classification of business activities of the EU (NACE), WPI consists of three sections that can be characterized from the view of value-added creation as follows:

- NACE 16: primary mechanical wood processing (timber industry)—semi-finished products with low value added;

- $\quad$ NACE 17: primary and secondary chemical wood processing (pulp and paper industry) - a hybrid sector including semi-products with low value added (pulp and paper) and final products of the highest value added (paper products) within WPI;

- NACE 31: secondary wood processing (the furniture industry) - final products of a high value added.

The methodological procedure of the study was suggested as follows:

- Research propositions establishment

- Selection of methods for statistical analysis

- Formation of indicators assessing the effects of foreign trade on the economic performance of industry

- Input data collection: the main source of input data is official statistical data of the countries and industries

- Analysis of data by statistical methods

- Testing assumptions and models for statistical and econometric analyses 
- Calculation of indicators' values

- Analysis of results achieved

- Verification of research propositions and discussion

- Conclusions and recommendations statement

To meet the objective of the study, the following research hypotheses were stated:

Hypothesis 1. Import of wood-based products influences economic performance of the wood processing industry negatively.

Hypothesis 2. Export of wood-based products has a positive impact on economic performance of the wood processing industry.

Hypothesis 3. Net export growth has a positive effect on the economic performance of the wood processing industry.

\subsection{Input Data}

The input data necessary for obtaining relevant outputs was gathered from official statistic data of exports, imports, and economic results of the wood processing industry in the Czech Republic and Slovakia. The data were collected from official databases for the period 2008-2018. The period of data collection was chosen due to two reasons. Year 2018 is the last year of data availability in economic indicators of the industries. In years before 2008 , the methodology of their statistical collection was different, so the consistency of time series would not be met. The length of time series represents a limitation in possibility to apply certain econometric models.

European Commission (2021) in Eurostat statistics database (https:/ / ec.europa.eu/ eurostat, accessed on 25 January 2021) provided annual data on the international trade of the countries-trade by NACE Rev. 2 activity and enterprise size class. The commodity structure of EU trade by CPA 2008 (FOB/FOB) was examined too.

The data concerning economic indicators of the WPI sectors, such as the value of production, sales, added value, and financial results before taxation were collected from two sources: Statistical Office of the Slovak Republic (2021) in Slovstat, datacube (http: / / datacube.statistics.sk, accessed on 25 January 2021) and the Ministry of Industry and Trade of the Czech Republic (2021) - A panorama of the manufacturing industry CR (http:/ / www.mpo.cz, accessed on 25 January 2021). The Czechia data were expressed in Czech currency (crowns) and were translated to euros by an average annual exchange rate of the national bank. The performance of the industry is represented by value added and profit. Sales are the main indicator of economic output.

\subsection{Indicators and Methods}

The indicators and methods used to assess the effects of international trade on economic growth applied in the relevant empirical studies were used at a macroeconomic level. For measurement and evaluation at a mesoeconomic (industry) level, the indicators needed to be modified. The terms of trade indicators could not be used because of input data unavailability.

Indicators representing economic performance of the industry are value added, profit, and their ratios to sales (value added rate and return on sales). The ratio indicators are suitable for a comparison of results in different countries.

The value-added rate (VAR) is the value added to the total turnover of the sector and can be calculated as follows (Sujová et al. 2015c):

$$
\mathrm{VAR}=\frac{V A}{S} \cdot 100
$$

where $V A$ is value added of the sector and $S$-sales of the sector. 
Return on sales (ROS) is a measure of how efficiently a company turns sales into profits. ROS is calculated by dividing operating profit by net sales (Sujová et al. 2015c):

$$
\text { ROS }=\frac{P}{S} \cdot 100,
$$

where $P$ is profit before tax of the sector and $S$-sales of the sector.

The next analysis was focused on the foreign trade of the industry by quantifying (1) the export share of WPI to the whole industry, (2) the share of WPI import to its export, (3) the ratio of the sector export to its sales, and (4) the comparative advantages of the WPI. The comparative advantages were identified by a modified RCA indicator of a revealed comparative advantage (RCA). The RCA indicator represents the trade competitiveness and the following calculation formula is used (Aiginger and Landesmann 2002):

$$
\mathrm{RCA}=\ln \left[\left(x_{i j} / m_{i j}\right):\left(X_{j} / M_{j}\right)\right.
$$

where $x_{i j}$ is the export of industry " $i$ " in country " $j$ "; $m_{i j}$ is the import of industry " $i$ " in country " $j$ "; $X_{j}$ is total exports from country " $j$ "; and $M_{j}$ is the total imports to country " $j$ ".

If the value $\mathrm{RCA}<0$, it indicates a comparative disadvantage of the industry; if RCA $>0$, the export of the industry and its commodities has a comparative advantage in the country, and RCA $>1$ identifies that industry is competitive on international markets.

The growth rate of parts of a trade balance $\left(G_{X}\right)$ expresses the development trend in foreign trade indicators. It was needed to calculate them for the analysis and correct interpretation of the obtained results:

$$
G_{X}=\left(\frac{X_{t}}{X_{t-1}}-1\right) \cdot 100
$$

where $X$ is the value of a part in the trade balance (export, import, and net export), $t$ is the period (year).

The positive value of $G$ indicates the growth of import, export or net export, the negative values mean the decrease of indicators.

The relationship between economic indicators of WPI and components of foreign trade (import and export) of the industry were examined by multivariate linear regression (MLR) analysis. MLR method is used to assess the association between two or more independent variables and a single continuous dependent variable. The multiple linear regression equation in the analysis was as follows:

$$
\mathrm{Y}_{t}=\beta_{0}+\beta_{1} X_{t 1}+\beta_{2} X_{t 2}+u_{t}
$$

where $\mathrm{Y}$ is the economic indicator (sales, value added, or profit before tax) of industry as predicted or expected value of the dependent variable, $X_{1}$ (import volume) and $X_{2}$ (export volume) are distinct independent or predictor variables, $\beta_{0}$ is the value of $Y$ when the independent variables $\left(X_{1}\right.$ and $\left.X_{2}\right)$ are equal to zero, and $\beta_{1}$ and $\beta_{2}$ are the estimated regression coefficients.

Each regression coefficient represents the change in $Y$ relative to a one-unit change in the respective independent variable. In the multiple regression situation, $\beta_{1}$ is the change in $Y$ relative to a one-unit change in $X_{1}$, holding all other independent variables constant (i.e., when the remaining independent variables are held at the same value or are fixed). Statistical tests can be performed to assess whether each regression coefficient is significantly different from zero.

Additive stochastic term $u_{t}$ was assumed. The least squares method (OLS) was used to estimate the MLR parameters. The OLS method provides unbiased and efficient estimates if the classical assumptions of the regression model are met (see Gujarati 2003).

In addition to the standard $\mathrm{t}$ and $\mathrm{F}$ tests used in regression model, statistical tests that check if autocorrelation exists in a time series were applied. One of the main assumptions 
in linear regression is that there is no correlation between consecutive residuals, it is assumed that the residuals are independent. The first order autocorrelation by the LjungBox test was tested (Ljung and Box 1978). The Ljung-Box test is also appropriate for small samples. If the $p$-value of the test is greater than 0.05 , the residuals for the time series model are independent, which is often an assumption made when creating a model. The test statistic is:

$$
\mathrm{Q}=\mathrm{n}(\mathrm{n}+2) \Sigma \mathrm{p}_{\mathrm{k}}^{2} /(\mathrm{n}-\mathrm{k})
$$

where $\mathrm{n}$ is the sample size, $\Sigma$ is taken as the sum of 1 to $\mathrm{h}$, where $\mathrm{h}$ is the number of lags being tested, $\mathrm{pk}$ is the sample autocorrelation at lag $\mathrm{k}$.

The test statistic $Q$ follows a chi-square distribution with h degrees of freedom; that is, $\mathrm{Q} \sim \mathrm{X}^{2}(\mathrm{~h})$. We reject the null hypothesis and say that the residuals of the model are not independently distributed if $Q>X^{2}{ }_{1}-\alpha, h$.

The linear specification of the regression model is verifying by the Ramsey RESET test. It tests whether non-linear combinations of the fitted values help explain the response variable. The intuition behind the test is that if non-linear combinations of the explanatory variables have any power in explaining the response variable, the model is misspecified in the sense that the data generating process might be better approximated by a polynomial, or another non-linear functional form (Ramsey 1969).

The normality of residuals was tested by the Jarque-Bera test. It is a goodness-of-fit test of whether sample data have the skewness and kurtosis matching a normal distribution. If it is far from zero, it signals the data do not have a normal distribution. According to Hall et al. (1995), when using this test along with multiple regression analysis the right estimate is:

$$
J B=(\mathrm{n}-\mathrm{k}) / 6\left(\mathrm{~S}^{2}+1 / 4(\mathrm{~K}-3)^{2}\right)
$$

where $\mathrm{n}$ is the number of observations and $\mathrm{k}$ is the number of regressors when examining residuals to an equation.

Annual data are used in the analysis; therefore, the ARCH testing is not required. All test procedures by the Ljung-Box test, Ramsey RESET test, and the Jarque-Bera test are discussed in Greene (2003).

At the same time, since we estimate the parameters of models where the variables are time series, to avoid the problem of spurious regression, used variables should be generated by stationary processes. Dickey-Fuller test is used to determine whether a unit root is present in an autoregressive model. The extension of the Dickey-Fuller test called the augmented Dickey-Fuller test (ADF) was used to test the stationarity of time series. ADF test removes all the structural effects (autocorrelation) in the time series and then tests using the same procedure. If the calculated tau value is less than the critical value in the table of critical values, then we have a significant result, and the time series is stationary (Dickey and Fuller 1979).

If the time series is a stationary process, the Granger causality test can be performed using the level values of two (or more) variables. If it is not the case, then differencing, de-trending, or other techniques must first be employed before using the Granger causality test. The Granger causality test assumes that the information relevant to the prediction of the variables is contained in the time series data of these variables. It is tested whether the lagged values of $x$ affect $y$ and vice versa. The Granger causality test is very sensitive to the number of lags used in the analysis. The null hypothesis expresses that the parameter for the lagged explanatory variables is equal to zero. If a given $p$-value is < significance level (0.05), we can reject the null hypothesis and conclude that x Granger causes y (Granger 1969).

Multivariate Granger causality analysis is usually performed by fitting a vector autoregressive model (VAR) to the time series and consequently by the Johansen cointegration analysis or estimating the ARDL models. The short time series analyzed in the paper allow to create VAR model only by one lag and a consequent cointegration model is not possible to create. 
The Granger causality test can determine whether one time series is useful in forecasting another. It may be found that one or neither variable Granger-causes the other or that each of two variable Granger-causes the other. It means that Granger causality can be unidirectional or bidirectional. The statistical analysis of MLR can indicate association between economic performance and foreign trade (import and export) under condition that one of a trade balance side does not change. However, the export and import volumes are changing simultaneously and a deeper analysis considering the dynamics in import and export development is needed to analyze the impacts of a trade balance on the economic indicators.

The next part of this phase was the design of indicators to measure the effects of foreign trade on industry performance by modifying macroeconomic indicators used by Breda et al. (2007) and Hajnovičová (2008). The contribution of foreign trade (CFT) to the economic growth of the industry was applied. The indicator quantifies the impact of a trade balance to annual growth of the economic indicator in industry. Its calculation formula is as follows:

$$
\mathrm{CFT}=\left(\frac{\mathrm{EX}_{\mathrm{t}}}{\mathrm{EX}_{\mathrm{t}-1}}-1\right) \cdot\left(\frac{\mathrm{EX}_{\mathrm{t}-1}}{\mathrm{Y}_{\mathrm{t}-1}}\right)-\left(\frac{\mathrm{IM}_{\mathrm{t}}}{\mathrm{IM}_{\mathrm{t}-1}}-1\right) \cdot\left(\frac{\mathrm{IM}_{\mathrm{t}-1}}{\mathrm{Y}_{\mathrm{t}-1}}\right)
$$

where EX is industry's export; IM is industry's; and $\mathrm{Y}$ is an industry's economic indicator (sales, value added, profit).

The values of CFT indicator show that trade balance has a positive impact on the industry's economic performance if CFT $>0$ and the CFT $<0$ indicates the negative effect of net export on the industry's economic indicator.

The second measure used in the study was the transformation effect of an economy (TEE). TEE indicates the relationship between import of input material $(\mathrm{Mi})$ and export of the industry $(X j)$. Its calculation is expressed in Equation (9). The TEE index, needed for the appropriate interpretation of the results, is calculated in Equation (10).

$$
\begin{gathered}
\mathrm{TEE}=\frac{M i}{X j} \cdot 100 \\
\mathrm{TEE}_{i}=\frac{(X j-M i)_{t}}{(X j-M i)_{t-1}}-1
\end{gathered}
$$

Based on a calculation of the designed indicators, the paper assessed the effects of foreign trade on the performance of sectors WPI in Czechia and Slovakia for a ten-year period (2009-2018). Comparing the growth rates of imports, exports, and net exports $\left(G_{x}\right)$ with values of CFT indicators, the effects of trade balance on industry's economic indicators can be identified and analyzed in more detail.

\section{Results}

This section presents and analyses the results achieved in the study. The analysis was applied to the wood processing industry (WPI) of Czechia and Slovakia.

In monitored countries, WPI represents a comparable share of GDP at a level near 4\%. During the monitored period of the last ten years, the share of WPI exports in relation to national exports was at an average level of $4.2 \%$ in both countries. The trend of performance indicators was growing except for the period 2011-2013 when the decline was recorded. A surplus of the foreign trade balance during the monitored period has gradually fallen in WPI of Slovakia.

\subsection{Economic Performance of WPI in Czechia and Slovakia}

The level of economic performance in wood processing industry is presented by reached values in value added, profit before tax, value added rate, and return on sales. The average values of the indicators enable a comparison the economic performance of WPI in two monitored countries, Czechia and Slovakia. The results are presented in Table 1. 
Table 1. The average economic performance in WPI sectors of Slovakia (SVK) and Czechia (CZ) in the period 2008-2018.

\begin{tabular}{|c|c|c|c|c|c|}
\hline Indicator & $\begin{array}{l}\text { Sales } \\
\text { (mil. €) }\end{array}$ & $\begin{array}{l}\text { Value Added } \\
\text { (mil. } € \text { ) }\end{array}$ & $\begin{array}{l}\text { Profit before Tax } \\
\text { (mil. } € \text { ) }\end{array}$ & $\begin{array}{c}\text { Value Added Rate } \\
(\%)\end{array}$ & $\begin{array}{c}\text { Return on Sales } \\
(\%)\end{array}$ \\
\hline WPI SVK & 3313.048 & 754.658 & 353.101 & 22.77 & 10.58 \\
\hline WPI CZ & 6794.207 & 1868.846 & 518.183 & 27.46 & 7.49 \\
\hline
\end{tabular}

Source: own calculation based on data of MIR CR and Slovak Statistical Office.

The average amount of sales is two times higher, and value added is 2.5 times higher in the Czech WPI than in the Slovak WPI. However, the difference between average value of profit before tax is less than double. It corresponds to average ratio indicators; value-added rate is higher in the Czechia in almost 5\%, while the return on sales is lower by $3 \%$ in comparison with results in Slovakia.

The trend of economic indicators development is presented by trend indices in Table 2.

Table 2. The indices of economic performance in the Slovak and Czech WPI.

\begin{tabular}{|c|c|c|c|c|c|c|c|c|c|c|c|}
\hline Indicator's Index & 2009 & 2010 & 2011 & 2012 & 2013 & 2014 & 2015 & 2016 & 2017 & 2018 & Average \\
\hline \multicolumn{12}{|l|}{ WPI SVK } \\
\hline Sales & 0.88 & 1.32 & 0.93 & 0.99 & 1.03 & 1.13 & 1.07 & 0.92 & 1.05 & 1.09 & 1.04 \\
\hline Value added & 1.01 & 1.64 & 0.93 & 0.83 & 1.00 & 1.08 & 1.10 & 0.99 & 1.02 & 1.05 & 1.06 \\
\hline Profit before tax & 1.49 & 2.58 & 0.90 & 0.71 & 1.07 & 0.99 & 1.11 & 1.00 & 0.97 & 0.97 & 1.18 \\
\hline Value added rate & 1.14 & 1.24 & 1.00 & 0.83 & 0.97 & 0.96 & 1.03 & 1.09 & 0.97 & 0.96 & 1.02 \\
\hline Return on Sales & 1.69 & 1.95 & 0.97 & 0.72 & 1.05 & 0.88 & 1.04 & 1.10 & 0.92 & 0.89 & 1.12 \\
\hline \multicolumn{12}{|l|}{ WPI CZ } \\
\hline Sales & 0.89 & 1.09 & 1.07 & 0.96 & 0.98 & 1.01 & 1.07 & 1.03 & 1.08 & 1.07 & 1.0 \\
\hline Value added & 0.92 & 1.05 & 1.00 & 0.98 & 0.98 & 1.03 & 1.09 & 1.06 & 1.10 & 1.10 & 1.0 \\
\hline Profit before tax & 0.75 & 1.19 & 1.00 & 0.99 & 0.99 & 1.35 & 1.11 & 1.22 & 1.09 & 1.08 & 1.1 \\
\hline Value added rate & 1.03 & 0.97 & 0.94 & 1.02 & 1.00 & 1.02 & 1.01 & 1.03 & 1.02 & 1.03 & 1.0 \\
\hline Return on Sales & 0.85 & 1.09 & 0.94 & 1.02 & 1.01 & 1.33 & 1.04 & 1.18 & 1.01 & 1.01 & 1.0 \\
\hline
\end{tabular}

Source: own calculation based on data of MIR CR and Slovak Statistical Office.

In Slovak WPI, the decline of sales was noticed in years 2009, 2011, and 2016 by 7-12\%. Value added decreased only in two years, 2011 and 2012, but value-added rate had a negative falling trend in more years, in 2012, 2013, 2014, 2017, and 2018. The biggest decrease was recorded in the profit and profitability, by 29\% in 2012 and in years 2011, 2017, and 2018. However, in the average, the economic performance increased in all indicators. The highest increase was in the profit by $18 \%$ and in profitability by $12 \%$ per ten-year period. WPI in Czechia showed a stable level of economic performance, a slight decline was recorded in 2009 . The average increase by $10 \%$ per ten years was in profit.

\subsection{Foreign Trade Analysis}

Export performance and competitiveness of the WPI in Czechia and Slovakia were evaluated using ratio indicators and the RCA index. The results are presented in Table 3.

The data in Table 3 show that trade balance was active in WPI of both countries during the period analyzed. While the trade balance surplus in the Czech WPI was gradually growing, in the Slovak WPI a declining trend was noticed. The import to export ratio revealed that more than three thirds of exported wood-based products was imported back to Czechia; in Slovakia it has gradually grown from 65 to $95 \%$. The proportion of WPI export to national export remains level at $4.23 \%$ on average in Czechia, in Slovakia it gradually fell from 5.6 to $4.1 \%$. The export performance gradually grew in both countries during monitored period, the decline was noticed in the last year 2018. The higher export performance was reached in the Czech WPI, at a level of over $88 \%$ in last two years. The Slovak WPI reached an average export performance of $80 \%$ and for the Czech WPI it was $79.5 \%$. The index RCA revealed that WPI has a comparative advantage at the national 
level. The higher values of the RCA index were observed in the Slovak WPI in first two years, but the advantage gradually decreased. The Czech WPI maintained a higher level of comparative advantage (0.14-0.24), but the trend was decreasing during the reference period. The comparative advantage of this sector in both countries is disappearing.

Table 3. Foreign Trade Analysis of WPI.

\begin{tabular}{ccccccccccc}
\hline Indicator & $\mathbf{2 0 0 9}$ & $\mathbf{2 0 1 0}$ & $\mathbf{2 0 1 1}$ & $\mathbf{2 0 1 2}$ & $\mathbf{2 0 1 3}$ & $\mathbf{2 0 1 4}$ & $\mathbf{2 0 1 5}$ & $\mathbf{2 0 1 6}$ & $\mathbf{2 0 1 7}$ & $\mathbf{2 0 1 8}$ \\
\hline WPI CZ & & & & & & & & & \\
\hline Net export (mil. €) & 748.22 & 1084.8 & 1239.7 & 1232.5 & 1449.4 & 1464.0 & 1327.2 & 1180.2 & 1320.6 & 1305.5 \\
IM EX (\%) & 80.1 & 74.8 & 73.8 & 74.1 & 71.8 & 73.5 & 77.9 & 81.2 & 81.0 & 82.0 \\
Share in export CZ (\%) & 4.64 & 4.29 & 4.03 & 3.89 & 4.21 & 4.20 & 4.21 & 4.28 & 4.31 & 4.23 \\
Share of exports in sales (\%) & 64.37 & 67.96 & 69.94 & 73.13 & 80.94 & 85.93 & 86.67 & 87.97 & 90.30 & 88.05 \\
RCA & 0.15 & 0.24 & 0.24 & 0.20 & 0.21 & 0.18 & 0.14 & 0.08 & 0.14 & 0.11 \\
\hline WPI SVK & & & & & & & & & & \\
\hline Net export (mil. €) & 788.032 & 562.827 & 505.42 & 513.19 & 511.44 & 500.41 & 398.46 & 218.66 & 295.61 & 162.53 \\
IM/EX (\%) & 65.21 & 75.02 & 78.09 & 78.70 & 79.51 & 80.02 & 85.33 & 92.37 & 90.17 & 95.03 \\
Share in export SVK (\%) & 5.63 & 4.53 & 4.03 & 3.84 & 3.87 & 3.86 & 4.01 & 4.12 & 4.08 & 4.13 \\
Share of exports in sales (\%) & 89.61 & 67.34 & 74.44 & 78.64 & 79.47 & 70.73 & 71.93 & 82.90 & 82.59 & 82.16 \\
RCA & 0.42 & 0.30 & 0.25 & 0.20 & 0.18 & 0.17 & 0.13 & 0.05 & 0.13 & 0.05 \\
\hline
\end{tabular}

Source: own calculation based on data of Eurostat.

\subsection{Results of Multivariate Linear Regression}

Multivariate Linear Regression method was applied to find out association between indicators of economic performance in wood processing industry and foreign trade represented by independent variables of export and import values. The analysis in the Czech WPI brought results presented in Tables 4 and 5 .

Table 4. Linear Multiple Regression of Czech WPI.

\begin{tabular}{|c|c|c|c|c|}
\hline Sales on Import and Export $(i=0,1,2)$ & $\beta_{i}$ & $\beta_{I}($ Std. Error) & $t$-Test & $p$-Value \\
\hline Intercept $\left(\beta_{0}\right)$ & $5,179,165.26$ & $319,835.81$ & 16.19 & $(0.000)$ \\
\hline Import $\left(\beta_{1}\right)$ & 1.66 & 0.29 & 5.82 & $(0.000)$ \\
\hline Export $\left(\beta_{2}\right)$ & -0.99 & 0.17 & -5.68 & $(0.000)$ \\
\hline Value Added on Import and Export $(i=0,1,2)$ & $\beta_{i}$ & $\beta_{I}($ Std. Error) & $t$-Test & $p$-Value \\
\hline Intercept $\left(\beta_{0}\right)$ & $1,259,144.21$ & $81,165.43$ & 15.51 & $(0.000)$ \\
\hline Import $\left(\beta_{1}\right)$ & 0.61 & 0.07 & 8.44 & $(0.000)$ \\
\hline Export $\left(\beta_{2}\right)$ & -0.36 & 0.04 & -8.18 & $(0.000)$ \\
\hline Profit on Import and Export $(i=0,1,2)$ & $\beta_{i}$ & $\beta_{I}$ (Std. Error) & $t$-Test & $p$-Value \\
\hline Intercept $\left(\beta_{0}\right)$ & $74,813.05$ & $46,773.52$ & 1.60 & $(0.148)$ \\
\hline Import $\left(\beta_{1}\right)$ & 0.46 & 0.04 & 11.14 & $(0.000)$ \\
\hline Export $\left(\beta_{2}\right)$ & -0.28 & 0.03 & -10.91 & $(0.000)$ \\
\hline
\end{tabular}

Table 5. Multiple Regression Models Summary of Czech WPI.

\begin{tabular}{cccc}
\hline Multiple Regression Model Summary-CZ & Sales & Value Added & Profit before Tax \\
\hline Multiple $R$ & 0.90 & 0.95 & 0.97 \\
Multiple $R^{2}$ & 0.81 & 0.90 & 0.94 \\
Adjusted $R^{2}$ & 0.76 & 0.88 & 0.92 \\
F-test & 17.17 & 36.53 & 62.41 \\
p-value & 0.001 & 0.000 & 0.000 \\
St. Error of Estimate & $329,383.91$ & $83,588.48$ & $48,169.86$ \\
\hline
\end{tabular}


Performed F-test by association between sales and foreign trade in the Czech WPI reveals that multiple regression model $Y=5.18 \times 10^{6}+1.66 X_{1}-0.99 X_{2}$ is highly significant $(p=0.001)$. Both partial regression coefficients are significantly different from zero. The value of the estimated partial regression coefficient $\beta_{1}$ implies that an estimated mean increase of $1.66 €$ of sales is associated with unit change in variable Import, if variable export is held constant at any level. The value of $\beta_{2}$ implies an estimated mean decrease $0.99 €$ of sales with unit change in variable export if import is similarly held constant.

Analysis of relationship between value added and foreign trade showed that performed $F$-test reveals that multiple regression model $Y=1.26 \times 10^{6}+0.61 X_{1}-0.36 X_{2}$ is highly significant $(p=0.000)$. Both of partial regression coefficients are significantly different from zero. The value of the estimated partial regression coefficient $\beta_{1}$ implies that an estimated mean increase of $0.61 €$ of value added is associated with unit change in variable import, if variable export is held constant at any level. The value of $\beta_{2}$ implies an estimated mean decrease $0.36 €$ of value added with unit change in variable export if import is similarly held constant.

Multivariate regression analysis of profit before tax reveals according to the performed $F$-test that model $Y=7.48 \times 10^{5}+0.46 X_{1}-0.28 X_{2}$ is highly significant $(p=0.000)$. Both partial regression coefficients are significantly different from zero. The value of the estimated partial regression coefficient $\beta_{1}$ implies that an estimated mean increase of $0.46 €$ of profit is associated with unit change in variable import, if variable export is held constant at any level. The value of $\beta_{2}$ implies an estimated mean decrease $0.28 €$ of profit with unit change in variable export if import is similarly held constant.

The sample coefficients of multiple determination in Table 5 indicate that $76 \%$ proportion of the total variation in sales, $88 \%$ proportion of the total variation in value, and $92 \%$ proportion of the total variation in profit before tax are explained by the given multiple regression models.

The assumptions of regression models were tested by Ljung-Box autocorrelation test, Ramsey RESET test and Jarque and Bera normality test. The results for the Czech WPI are shown in Table 6.

Table 6. Tests of Assumption of Multiple Regression Models of Czech WPI.

\begin{tabular}{cccc}
\hline MLR Assumption Test-CZ & Sales & Value Added & Profit before Tax \\
\hline Ljung-Box test (Q-Stat) & 0.426 & 0.667 & 0.027 \\
Ljung-Box test ( $p$-value) & $(0.514)$ & $(0.414)$ & $(0.869)$ \\
Jarque-Bera (Stat) & 0.753 & 0.218 & 3.028 \\
Jarque-Bera ( $p$-value) & $(0.686)$ & $(0.218)$ & $(0.220)$ \\
RESET test (F-stat) & 2.238 & 12.653 & 0.148 \\
RESET test $(p$-value) & $(0.188)$ & $(0.007)$ & $(0.865)$ \\
\hline
\end{tabular}

Source: own calculation.

According to the Ljung-Box autocorrelation test, there is no first order or higher order autocorrelation in regression equations. The results of the Jarque and Bera normality test show that the residuals are normally distributed in each equation. Due to the normality, the test of statistical significance of the individual model coefficients ( $t$ test) and the test of the overall significance ( $F$ test) have the corresponding distributions in case of the small sample. The RESET test is a general test of specification error. It is a way of testing whether there exist some significant nonlinear relationships when you have built a linear regression model. The results of the test in the equation for sales and profit confirm the selected linear specification of regression model. The probability values ( $p$-values) of all performed tests are in the parentheses.

The results of multiple linear regression in the Slovak wood processing industry are presented in Tables 7 and 8 . 
Table 7. Linear Multiple Regression of Slovak WPI.

\begin{tabular}{|c|c|c|c|c|}
\hline Sales on Import and Export $(i=0,1,2)$ & $\beta_{i}$ & $\beta_{i}$ (Std. Error) & $t$-Test & $p$-Value \\
\hline Intercept $\left(\beta_{0}\right)$ & $2,201,762.71$ & $292,487.80$ & 7.53 & 0.000 \\
\hline $\operatorname{Import}\left(\beta_{1}\right)$ & 0.85 & 0.19 & 4.41 & 0.002 \\
\hline Export $\left(\beta_{2}\right)$ & -0.26 & 0.06 & -4.70 & 0.002 \\
\hline Value Added on Import and Export $(i=0,1,2)$ & $\beta_{i}$ & $\beta_{I}($ Std. Error) & $t$-Test & $p$-Value \\
\hline Intercept $\left(\beta_{0}\right)$ & $597,394.57$ & $112,656.25$ & 5.30 & 0.001 \\
\hline Import $\left(\beta_{1}\right)$ & 0.15 & 0.07 & 1.99 & 0.081 \\
\hline Export $\left(\beta_{2}\right)$ & -0.05 & 0.02 & -2.54 & 0.035 \\
\hline Profit on Import and Export $(i=0,1,2)$ & $\beta_{i}$ & $\beta_{I}($ Std. Error) & $t$-Test & $p$-Value \\
\hline Intercept $\left(\beta_{0}\right)$ & $354,901.30$ & $103,580.89$ & 3.43 & 0.009 \\
\hline Import $\left(\beta_{1}\right)$ & 0.04 & 0.07 & 0.60 & 0.564 \\
\hline Export $\left(\beta_{2}\right)$ & -0.03 & 0.02 & -1.34 & 0.218 \\
\hline
\end{tabular}

Table 8. Multiple Regression Models Summary of Slovak WPI.

\begin{tabular}{cccc}
\hline Multiple Regression Model Summary-SVK & Sales & Value added & Profit before Tax \\
\hline Multiple $R$ & 0.86 & 0.72 & 0.69 \\
Multiple $R^{2}$ & 0.73 & 0.52 & 0.48 \\
Adjusted $R^{2}$ & 0.67 & 0.40 & 0.35 \\
F-test & 11.08 & 4.37 & 3.69 \\
p-value & 0.005 & 0.052 & 0.073 \\
St. Error of Estimate & $243,968.04$ & $93,968.10$ & $86,398.23$ \\
\hline
\end{tabular}

Source: own calculation.

Analysis of relationship between sales and foreign trade in the Slovak WPI showed that performed $F$-test reveals that multiple regression model $Y=2.20 \times 10^{6}+0.85 X_{1}-$ $0.26 X_{2}$ is highly significant $(p=0.005)$. Both partial regression coefficients are significantly different from zero. The value of the estimated partial regression coefficient $\beta_{1}$ implies that an estimated mean increase of $0.85 €$ of sales is associated with unit change in variable import, if variable export is held constant at any level. The value of $\beta_{2}$ implies an estimated mean decrease $0.26 €$ of sales with unit change in variable export if import is similarly held constant.

By association between value added and foreign trade, the performed $F$-test reveals that multiple regression model $Y=5.97 \times 10^{5}+0.15 X_{1}-0.05 X_{2}$ is significant only in relation to export $(p=0.035)$. The value of $\beta_{2}$ implies an estimated mean decrease $0.05 €$ of value added with unit change in variable export if import is similarly held constant.

Multivariate regression analysis of profit before tax did not reveal a statistical significance of model $Y=3.54 \times 10^{5}+0.05 X_{1}-0.03 X_{2}(p=0.073)$.

The sample coefficients of multiple determination in Table 7 indicate that $67 \%$ proportion of the total variation in sales, $40 \%$ proportion of the total variation in value, and $35 \%$ proportion of the total variation in profit before tax are explained by the given multiple regression models.

Results of testing assumptions for MLR models for Slovak WPI are shown in Table 9. According to the Ljung-Box autocorrelation test, there is no first order or higher order autocorrelation in regression equations. The results of the Jarque and Bera normality test show that the residuals are normally distributed in each equation. The results of the RESET test confirm the selected linear specification in the equation for sales, profit, and value added. 
Table 9. Tests of Assumption of Multiple Regression Models of Slovak WPI.

\begin{tabular}{cccc}
\hline MLR Assumption Test-SVK & Sales & Value Added & Profit before Tax \\
\hline Ljung-Box test (Q-Stat) & 0.492 & 0.245 & 0.599 \\
Ljung-Box test $(p$-value) & $(0.483)$ & $(0.621)$ & $(0.439)$ \\
Jarque-Bera (Stat) & 0.563 & 0.818 & 0.272 \\
Jarque-Bera $(p$-value) & $(0.755)$ & $(0.664)$ & $(0.873)$ \\
RESET test $(F$-stat) & 1.501 & 0.327 & 4.686 \\
RESET test $(p$-value) & $(0.296)$ & $(0.733)$ & $(0.059)$ \\
\hline
\end{tabular}

Source: own calculation.

A stationary time series is one whose statistical properties such as mean, variance, and autocorrelation are all constant over time. Dickey and Fuller have developed a threeversion unit root test that differs in the presence of different deterministic terms in the test equation. They proposed a unit root test without a deterministic term, a unit root test with a drift, and a unit root test with a drift and a deterministic time trend. The large number of results associated with unit root testing led us to select only the statistics of those test models that were statistically appropriate for the decision. From the results shown in Table 10 can be seen that all time series were generated by stochastic processes.

Table 10. Unit root test.

\begin{tabular}{cccc}
\hline Variable & $\tau$-Statistic & $p$-Value & Critical Value \\
\hline Value added_cz & -5.803 & $(<0.01)$ & -5.176 \\
Sales_cz & -6.160 & $(<0.01)$ & -4.363 \\
Profit before tax_cz & -4.823 & $(0.0557)$ & $-4.607(10 \%$ level $)$ \\
Import_cz & -61.388 & $(<0.01)$ & -4.525 \\
Export_cz & -98.990 & $(<0.01)$ & -4.525 \\
Value added_sk & -21.886 & $(<0.01)$ & -4.859 \\
Sales_sk & -6.459 & $(<0.01)$ & -4.859 \\
Profit before tax_sk & -16.467 & $(<0.01)$ & -4.525 \\
Import_sk & -43.525 & $(<0.01)$ & -4.525 \\
Export_sk & -100.186 & $(<0.01)$ & -4.444 \\
\hline
\end{tabular}

Source: own calculation.

Although the power of the Dickey and Fuller test is considered weak and the test is recommended to be performed for larger samples; the problem of the test is the inappropriate acceptance of non-stationarity (null hypotheses), when it is not true; which is not our case.

It can be concluded that time series except the profit before tax in Czechia appear to be generated by stationary processes at $5 \%$ level of significance and the time series of the profit before tax in Czechia appears to be generated by stationary processes at $10 \%$ level of significance.

The assumption for Granger causality test that the time series are stationary processes were confirmed and the Granger causality tests could be performed. We had to select only one lag, because the time series are too short. Granger causality test results in Table 11 suggest that the direction of Granger causality is from explanatory variables to dependent variable and on the other hand, there is no reverse causation from dependent variable to explanatory variables related to Slovakia. It means that in the case of forecasts, the addition of one lagged explanatory variable to the model would be beneficial. There is bilateral causality for variables related to Czechia. It means that it would be appropriate to estimate the VAR model. 
Table 11. Granger causality test.

\begin{tabular}{|c|c|c|}
\hline Predictor & Response & $p$-Value \\
\hline \multicolumn{3}{|l|}{ WPI SVK } \\
\hline import_sk & added_value_sk & 0.0466 \\
\hline added_value_sk & import & 0.1453 \\
\hline export_sk & added_value_sk & 0.0467 \\
\hline added_value_sk & export_sk & 0.2846 \\
\hline import_sk & profit_before_tax_sk & 0.0089 \\
\hline profit_before_tax_sk & import_sk & 0.3940 \\
\hline export_sk & profit_before_tax_sk & 0.0170 \\
\hline profit_before_tax_sk & export_sk & 0.7478 \\
\hline import_sk & sales_sk & 0.1204 \\
\hline sales_sk & import_sk & 0.0079 \\
\hline export_sk & sales_sk & 0.0708 \\
\hline sales_sk & export_sk & 0.0166 \\
\hline \multicolumn{3}{|l|}{ WPI CZ } \\
\hline import_cz & added_value_cz & 0.0331 \\
\hline added_value_cz & import_cz & 0.0027 \\
\hline export_cz & added_value_cz & 0.0265 \\
\hline added_value_cz & export_cz & 0.0047 \\
\hline import_cz & profit_before_tax_cz & 0.0364 \\
\hline profit_before_tax_cz & import_cz & 0.0000 \\
\hline export_cz & profit_before_tax_cz & 0.0350 \\
\hline profit_before_tax_cz & export_cz & 0.0000 \\
\hline import_cz & sales_cz & 0.0527 \\
\hline sales_cz & import_cz & 0.0031 \\
\hline export_cz & sales_cz & 0.0369 \\
\hline sales_cz & export_cz & 0.0029 \\
\hline
\end{tabular}

Source: own calculation.

Due to the low number of degrees of freedom, it was not possible to extend the analysis to dynamic autoregressive distributed lag models or to vector autoregressive models.

\subsection{Contribution of Trade Balance to WPI Economic Performance}

This part of the study presents results in indicators assessing the foreign trade impacts on WPI's economic performance. Two groups of indicators have been calculated: the contribution of foreign trade and the transformation effect of the economy. The indices representing the development trends of foreign trade components were calculated and included among results in this part so that comparison with contribution of foreign trade indicators could help explain the effects of foreign trade on economic performance. The results are shown in Table 12.

Data presented in Table 12 generated the following results. The wood processing industry in Czechia had higher growth in imports from 2013 than in the export of products. The growth of net export and export had a positive effect on its performance and it supported an increase of value added and profit. The sharp exports' increase in 2010 has influence on a growth in profit and value added despite import growth at most. CFT indicators showed that a decrease in net exports in 2015 and 2016 (while the imports growth was higher than exports) caused a significant decrease in value added and profit. Decrease of exports in 2009 influenced economic performance negatively too. However, net export only had a slight effect on sales. In years of little growth of net export, the foreign trade had almost no influence on economic indicators of the WPI. The transformation effect of the economy showed that the import of input wood materials contributed to the performance of the WPI in period 2010-2018, but the trend was falling. 
Table 12. Contribution of foreign trade to economic performance of Czech and Slovak WPI.

\begin{tabular}{ccccccccccc}
\hline Indicator & $\mathbf{2 0 0 9}$ & $\mathbf{2 0 1 0}$ & $\mathbf{2 0 1 1}$ & $\mathbf{2 0 1 2}$ & $\mathbf{2 0 1 3}$ & $\mathbf{2 0 1 4}$ & $\mathbf{2 0 1 5}$ & $\mathbf{2 0 1 6}$ & $\mathbf{2 0 1 7}$ & $\mathbf{2 0 1 8}$ \\
\hline WPI CZ & & & & & & & & & \\
\hline Growth rate of export (\%) & -81.00 & 14.67 & 9.65 & 0.64 & 8.28 & 7.45 & 8.38 & 4.84 & 10.67 & 4.08 \\
Growth rate of import (\%) & -76.13 & 7.13 & 8.09 & 1.07 & 5.02 & 9.98 & 14.76 & 9.37 & 10.39 & 5.31 \\
Growth rate of net export (\%) & -89.57 & 44.99 & 14.27 & -0.58 & 17.60 & 1.01 & -9.35 & -11.08 & 11.90 & -1.15 \\
CFT to sales & -0.98 & 0.06 & 0.02 & 0.00 & 0.03 & 0.00 & -0.02 & -0.02 & 0.02 & 0.00 \\
CFT to value added & -3.53 & 0.20 & 0.09 & 0.00 & 0.13 & 0.01 & -0.08 & -0.08 & 0.07 & -0.01 \\
CFT to profit & -14.79 & 1.03 & 0.40 & -0.02 & 0.56 & 0.04 & -0.27 & -0.26 & 0.20 & -0.02 \\
TEE (\%) & 14.63 & 13.34 & 12.63 & 13.06 & 11.67 & 11.77 & 11.64 & 11.90 & 12.04 & 12.55 \\
TEE $i$ & -0.832 & 0.164 & 0.106 & 0.001 & 0.100 & 0.073 & 0.085 & 0.045 & 0.105 & 0.035 \\
\hline WPI SVK & & & & & & & & & \\
\hline Growth rate of export (\%) & -87.92 & -0.54 & 2.41 & 4.44 & 3.58 & 0.36 & 8.46 & 5.49 & 4.96 & 8.72 \\
Growth rate of import (\%) & -77.32 & 14.43 & 6.61 & 5.25 & 4.64 & 1.01 & 15.65 & 14.19 & 2.46 & 14.57 \\
Growth rate of net export (\%) & -70.71 & -28.58 & -10.20 & 1.54 & -0.34 & -2.16 & -20.37 & -45.12 & 35.19 & -45.02 \\
CFT to sales & -3.99 & -0.09 & -0.02 & 0.00 & 0.00 & 0.00 & -0.03 & -0.05 & 0.02 & -0.04 \\
CFT to value added & -20.82 & -0.41 & -0.06 & 0.01 & 0.00 & -0.02 & -0.14 & -0.22 & 0.09 & -0.16 \\
CFT to profit & -85.26 & -1.12 & -0.11 & 0.02 & -0.01 & -0.03 & -0.29 & -0.46 & 0.20 & -0.35 \\
TEE (\%) & 15.58 & 17.38 & 15.60 & 17.08 & 16.80 & 15.65 & 15.61 & 15.84 & 15.82 & 15.90 \\
TEE $i$ & -0.896 & -0.027 & 0.046 & 0.026 & 0.039 & 0.018 & 0.085 & 0.052 & 0.050 & 0.086 \\
\hline
\end{tabular}

Source: own calculation based on data of Eurostat, MIR CR and Slovak Statistical Office.

Similar results were observed in the WPI of Slovakia. However, negative effect of net exports on that sector's performance was noticed during almost all years when the net export declined because of higher growth in imports than in exports. The sharp increase in imports in the years 2010 and 2016 caused a significant decrease in value added and profit despite export growth. The growth of net export due to higher growth in exports than in imports caused increased performance, especially in profits in the years 2012 and 2017. The stable imports of input materials for the WPI strengthened the transformation effect of the economy and contributed to economic performance of the Slovak WPI.

According to results obtained in CFT indicators, net export has a high influence on profit, a moderate influence on value added, and a slight influence on sales. Balanced foreign trade indicated no influence on economic performance of the industry in both countries.

\section{Verification of Research Hypotheses and Discussion}

Based on results presented in the previous section it is possible to verify research propositions stated.

Verification of Hypothesis 1. Import of wood-based products influences economic performance of the wood processing industry negatively.

The Granger causality test revealed unidirectional causality from import to value added and profit in the Slovak WPI and bidirectional causality in the Czech WPI. The multivariate regression models revealed a significant positive effect of import on profit, value added, and sales in the Czech WPI and on sales in the Slovak WPI in case if export does not change. The indicators CFT showed that imports have a positive effect on economic performance of industry only if there is a growth in imports lower than growth in exports and the net exports grow too.

The research Hypothesis 1 was not confirmed.

Verification of Hypothesis 2. Export of wood-based products has a positive impact on economic performance of the wood processing industry. 
The Granger causality test revealed unidirectional causality from export to value added and profit in the Slovak WPI and bidirectional causality in the Czech WPI. According to identified multivariate regression models, the export has a significant negative impact on all economic indicators in the Czech WPI and on sales and slightly on value added in the Slovak WPI in case the import remains the same. CFT indicators showed that a negative effect of export was noticed by its decline and by higher growth in imports than in export growth when the net export decreased. The growth in export and net export had a significant positive effect on profit and value added of WPI in both countries.

The research Hypothesis 2 was confirmed partially, only for case of export growth.

Verification of Hypothesis 3. Net export growth has a positive effect on the economic performance of the wood processing industry.

The results of CFT indicators revealed that an increase net export affects a growth in profit, value added, and slightly in sales in WPI only if the growth in imports was lower than in the exports of the sector's products.

Research Hypothesis 3 can be confirmed under the condition that net export growth is achieved by lower growth in imports than in exports of the industry.

Granger causality tests confirmed existing causality between foreign trade and economic performance of WPI in both countries while the time series were stationary. In the Slovak WPI it showed unidirectional causality from export to value added and profit as also from import to value added and profit. It can be stated that export and import Granger cause economic performance represented by indicators of value added and profit. As for sales, there is an opposite causality direction, it means that according to sales export and import can be predicted. In the Czech WPI, the Granger causality was revealed in both directions. It means that export and import Granger causes economic performance and vice versa.

Multivariate regression models revealed a direction of foreign trade influence on economic performance. The stronger influence was found out in the Czech WPI. According to MLR results, the imports increase all economic indicators, especially sales. The weak influence was revealed only by profit in the Slovak WPI. Considering the dynamics of foreign trade balance, CFT indicators showed that imports have a positive effect on economic performance only by keeping an active trade balance and the growth of net export. MLR models revealed a negative influence of exports on economic performance in the Czech WPI. In the Slovak WPI, the export growth relates to a slight decrease in value added and profit. However, CFT indicators showed a negative influence of export growth to economic performance only if the net export decreased.

Revealed positive effect of net export growth on the economic performance corresponds with the findings of Cetin (2016) and Awokuse (2007), but it is contradicted by results in other EU countries, as Blavasciunaite et al. (2020) discovered.

The analysis of the period 2000-2007 in previous work of authors (Sujová et al. 2015b) showed that increase in exports affects performance of WPI negatively in Slovakia, but positively in Czechia. It was also confirmed that import had a positive effect on the performance of the wood processing industry in Slovakia. This positive effect on the wood processing industries was not demonstrated in the Czech Republic. The positive effect of net export growth to economic performance of WPI in Slovakia and Czechia were demonstrated also for the previous period 2000-2007 analyzed in the works of authors in 2015 and 2016.

Based on results presented in the paper, it can be deduced that because of a specific abundant factor, raw wood material, the export in products of wood processing industry has a positive effect on the performance represented by value-added and profit indicators. On the contrary, a comparative advantage of the wood processing industry is disappearing in both countries.

The findings in the recent studies revealed that a barrier to the higher valorization of the national wood resources, is the high export of raw wood. Conversely, the import of 
goods produced by sectors of the wood processing industry stimulates the export growth of the industry. However, keeping the growth of imports under that of exports is needed, so the positive effects of foreign trade on the economic performance of the industry can be achieved.

In comparison with analyses from the previous period 2000-2009 (Sujová et al. 2015a), the share of WPI exports of national exports decreased from 5 to $2.7 \%$ in Slovakia and from 5 to $2.2 \%$ in Czechia, while the economic indicators of sales, profit, and value added were continually growing. Nevertheless, the value-added rate is still lower than in the Austrian WPI during the period 2000-2009, according to analysis by Sujová et al. (2015c). The difference is $3 \%$ in Czechia and $8 \%$ in Slovakia.

Keeping the growth of foreign trade with wood-based products is important for economic performance of the wood processing industry. Results of this study revealed that by balanced trade balance, only a little or no influence of foreign trade on economic performance was noticed.

\section{Conclusions}

The paper presented the effects of foreign trade on economic performance in wood processing industry based on a statistic analysis and designed indicators. According to Granger causality test, there is a Granger causality from foreign trade (export and import) to economic performance of the wood processing industry, unidirectional in Slovakia, and bidirectional in Czechia. Multivariate regression models and their assumptions tested for autocorrelation, normality, and linearity confirmed the reliability of MLR models. Multivariate regression revealed a positive effect of imports and a negative effect of exports on the economic performance of WPI in Slovakia and Czechia.

In comparison with existing studies, the contribution of the paper can be seen as expanding the knowledge of the impact of foreign trade on economic performance, at a mesoeconomic level, by using specific indicators, rather than general statistical methods. Designed indicators enable a deeper analysis of the background by assessing the impact of foreign trade on the performance and not only finding the positivity or negativity of the influence, as statistical methods do.

Developed countries aim to reach the highest valorization of national raw resources instead of their trading. However, the foreign trade of wood products in Czechia and Slovakia indicated much more intensive trade with products than a production increase. This means that most wood-based products are reexported. Thus, traders gain more than producers in the foreign trade of wood-based products in Czechia and Slovakia.

The findings in this study revealed that the positive effect of foreign trade on the performance of the manufacturing industry is kept or will be strong if the import growth is lower than the level of exports. Moreover, it is not desirable to restrict or prevent the import of products due to the negative effect on economic performance of decreasing imports. Net export should indicate the growth by the balanced trade balance no influence of foreign trade on economic performance appears.

To increase the economic performance of the wood processing industry in the Slovak and Czech Republic, the model optimizing the structure of foreign trade in wood-based products should be designed.

Policymakers should pay more attention to orienting measures and instruments toward the support of domestically sourced wood processing and manufacturing companies in the country. Conceptually, policymakers should create more favorable conditions for wood manufacturing companies than for traders with wood and wood-based products.

The study has some limitations. Shorter time series did not allow to extend the econometric analysis to dynamic autoregressive distributed lag models or to vector autoregressive models. The second limitation of the present study is the inability to examine the effects of foreign trade by the existence of a trade balance deficit. During the period monitored, as well as the previous period going back to 2000, the trade balance has been positive. 
The further direction of future research will be the investigation of model optimizing the structure of foreign trade in wood-based products and suggestion of appropriate and specific measures of economic policy that aim to support the economic performance of the wood processing sectors.

Author Contributions: Conceptualization, methodology, validation, investigation, writing—original draft preparation, review and editing A.S.; Validation, data curation, J.S. and A.L.; Formal analysis, resources, data curation, L.S.; Resources, V.K. All authors have read and agreed to the published version of the manuscript.

Funding: This research received no external funding.

Data Availability Statement: Data supporting reported results can be found in official statistical databases Eurostat (https:/ / ec.europa.eu/eurostat/web/international-trade-in-goods/data/focuson-enterprise-characteristics-tec, accessed on 25 January 2021), Slovak statistical Office (http:// datacube.statistics.sk/\#!!view/sk/VBD_SLOVSTAT/nu2056rs/v_nu2056rs_00_00_00_sk, accessed on 25 January 2021) and Ministry of Industry and Trade of the Czech Republic (https:/ /www.mpo. $\mathrm{cz} / \mathrm{cz} /$ panorama-interaktivni-tabulka.html, accessed on 25 January 2021).

Acknowledgments: This paper is supported by the project No. 005TU Z-4/2020 under the KEGA agency, Slovakia.

Conflicts of Interest: The authors declare no conflict of interest.

\section{References}

Afonso, Óscar. 2001. The Impact of International Trade on Economic Growth. Working Paper n ${ }^{\circ} 106$. Porto: Faculdade de Economia do Portol.

Aiginger, Karl, and Michael Landesmann. 2002. Competitive Economic Performance: The European View. WIFO Working Papers 179/2002. Vienna: Austrian Institute of Economic Research (WIFO).

Akeem, Usman Owolabi. 2011. Performance Evaluation of Foreign Trade and Economic Growth in Nigeria. Research Journal of Finance and Accounting 2: 1-15.

Antunes, António Jorge. 2012. The Effects of International Trade on Economic Growth: An Empirical Comparison between Portugal and the Netherlands. Lisbon: ISCTE Business School, 80p.

Awokuse, Titus. 2007. Causality between exports, imports, and economic growth: Evidence for transition economies. Economics Letters 94: 389-95. [CrossRef]

Belloumi, Mounir, and Atef Alshehry. 2020. The Impact of International Trade on Sustainable Development in Saudi Arabia. Sustainability 12: 5421. [CrossRef]

Blavasciunaite, Deimante, Lina Garsviene, and Kristina Matuzeviciute. 2020. Trade Balance Effects on Economic Growth: Evidence from European Union Countries. Economies 8: 54. [CrossRef]

Bobáková, Viktória, and Jaroslava Hečková. 2007. Competitiveness analysis of the Slovak processing industry. Politic Economy 4: 490-507.

Breda, Emanuele, Rita Cappariello, and Roberta Zizza. 2007. Measures the external trade impulse to economic growth: How relevant is the internalization of production? Paper presented at the 16th International Input-output Conference, Istanbul, Turkey, July 2-6, pp. 1-28.

Carvalho, Kaio Henrique Adame, Márcio Lopes Da Silva, and Naisy Silva Soares. 2009. Competitiveness of Brazilian wood pulp in the international market. Cerne 15: 383-390.

Cetin, Murat. 2016. The Impact of Energy Consumption, Trade Openness and Financial Development on Economic Growth: Empirical Evidence from Turkey (1980-2014). European Journal of Economics and Economics 18: 459-69.

Coronado, Carlos J., Eric McConnell, and Stephen N. Matthews. 2014. Economic impacts of timber product outputs in Ohio across timber market regions. BioResources 9: 7579-92. [CrossRef]

Dickey, David A., and Wayne A. Fuller. 1979. Distribution of the Estimators for Autoregressive Time Series with a Unit Root. Journal of the American Statistical Association 74: 427-31. [CrossRef]

Enu, Patrick, Emmanuel Dodzi Kutor Havi, and Edmond Hagan. 2013. The Impact of Foreign Trade on Economic Growth in Ghana (1980-2012). International Journal of Academic Research in Economics and Management Sciences 2: 174-91. [CrossRef]

European Commission. 2021. EUROSTAT Statistics Database. Available online: http:/ / epp.eurostat.ec.europa.eu/ (accessed on 25 January 2021).

Frankel, Jeffrey A., and David Romer. 1999. Does Trade Cause Growth? American Economic Review 89: 379-99. [CrossRef]

Ghirmay, Teame, Richard Grabowski, and Subhash C. Sharma. 2001. Exports, Investment, Efficiency, and Economic Growth in LDCs an empirical investigation. Applied Economics 33: 689-700. [CrossRef] 
Granger, Clive William John. 1969. Investigating Causal Relations by Econometric Models and Cross-spectral Methods. Econometrica 37: 424-38. [CrossRef]

Greene, William Harry. 2003. Econometric Analysis. Hoboken: Prentice Hall.

Gujarati, Damodar N. 2003. Basic Econometrics. New York: McGraw-Hill.

Hajdúchová, Iveta, and Petra Hlaváčková. 2014. Influence of global economy on forest-based sector in the Czech and Slovak Republic. Acta Facultatis Xylologiae 56: 135-46.

Hajnovičová, Viera. 2008. Measuring Influence of Foreign Trade on Economic Growth of SR. Working Papers No 8. Bratislava: Štatistický Ústav SAV.

Hall, Robert E., David M. Lilien, G. Syeyoshi, R. Engle, J. Johnston, and S. Ellsworth. 1995. EViews User Guide. Irvine: Quantitative Micro Software, p. 141.

Han, Xiao, Yali Wen, and Shashi Kant. 2009. The global competitiveness of the Chinese wooden furniture industry. Forest Policy and Economics 11: 561-69. [CrossRef]

Hobbs, Sam, Dimitrios E. Paparas, and Mostafa AboElsoud. 2021. Does Foreign Direct Investment and Trade Promote Economic Growth? Evidence from Albania. Economies 9: 1. [CrossRef]

Jeníček, Vladimír, and Vladimír Krepl. 2009. The role of foreign trade and its effects. Agricultural Economics 55: 211-20. [CrossRef]

Kong, Qunxi, Dan Peng, Yehui Ni, Xinyue Jiang, and Ziqi Wang. 2021. Trade openness and economic growth quality of China: Empirical analysis using ARDL model. Finance Research Letters 38: 101488. [CrossRef]

Kupčák, Václav, and Richard Pek. 2015. The level of the wood raw material base processing in the Czech Republic. Procedia Economics and Finance 34: 557-64. [CrossRef]

Lábaj, Martin, Mikuláš Luptáčik, and Daniela Rumpelová. 2008. Structural connections of the Slovak economy based on input-output analysis. Economic Journal 56: 745-63.

Lin, Shuanglin. 2000. Foreign Trade and China's Economic Development: A time-Series analysis. Journal of Economic Development 25: $145-53$.

Ljung, Greta M., and George Edward Pelham Box. 1978. On a Measure of a Lack of Fit in Time Series Models. Biometrika 65: 297-303. [CrossRef]

Makhmutova, Dilyara I., and Askar N. Mustafin. 2017. Impact of International Trade on Economic Growth. International Journal of Scientific Study 5: 140-44. [CrossRef]

Mandras, Giovanni, and Simone Salotti. 2020. An Input-Output Analysis of Sectoral Specialization and Trade Integration of the Western Balkans Economies. Economies 8: 93. [CrossRef]

Ministry of Industry and Trade of the Czech Republic. 2021. Panorama of Manufacturing Industry. Available online: https: / / www.mpo.cz/cz/panorama-interaktivni-tabulka.html (accessed on 25 January 2021).

Nazarczuk, Jaroslaw M., Stanislaw Umiński, and Krystyna Gawlikowska-Hueckel. 2018. The Role of Specialization in the Export Success of Polish Counties in 2004-15. Entrepreneurial Business and Economics Review 6: 91-109. [CrossRef]

Ramsey, James B. 1969. Tests for Specification Errors in Classical Linear Least Squares Regression Analysis. Journal of the Royal Statistical Society 31: 350-71. [CrossRef]

Ray, Salma. 2011. Exploring Co integration and Causality between Foreign Trade and Economic Growth: Econometric Evidence from India. International Journal of Contemporary Business Studies 2: 53-69.

Reppas, Panayiotis A., and Dimitris K. Christopoulos. 2005. The export-output growth nexus: Evidence from African and Asian countries. Journal of Policy Modeling 27: 929-40. [CrossRef]

Statistical Office of the Slovak Republic. 2021. Database Slovstat. Available online: http://slovak.statistics.sk (accessed on 25 January 2021).

Sujová, Andrea, Petra Hlaváčková, and Katrína Marcineková. 2015a. Evaluating the competitiveness of wood processing industry. Drona Industrija 66: 281-88. [CrossRef]

Sujová, Andrea, Petra Hlaváčková, and Katarína Marcineková. 2015b. Measuring the impact of foreign trade on performance of the wood processing industry. Wood Research 60: 49-501.

Sujová, Andrea, Petra Hlaváčková, and Dalibor Šafařík. 2015c. The analysis of performance in the wood processing industry through ratio indicators. Acta Facultatis Xylologiae 57: 165-78.

Sujová, Andrea, Jakub Michal, Václav Kupčák, and Roman Dudík. 2016. The Impact of International trade to the Growth of Forest-Based Sector in the Czech and Slovak Republics. BioResources 12: 1102-11. [CrossRef]

Sun, Peng, and Almas Heshmati. 2010. International Trade and Its Effects on Economic Growth in China. IZA Discussion Papers 5151. Bonn: Institute for the Study of Labor (IZA). Available online: https: / /ssrn.com/abstract=1667775 (accessed on 15 January 2021).

Wanat, Leszek, and Wojciech Lis. 2012. International competitiveness of the Polish wood industry from the mesoeconomic perspective. Transfer Inovácií 23: 7-12.

Were, Maureen. 2015. Differential effects of trade on economic growth and investment: A cross-country empirical investigation. Journal of African Trade 2: 71-85. [CrossRef]

Winters, L. Alan, and Andrew Masters. 2013. Openness and growth: Still an open question? Journal of International Development 25: 1060-70. [CrossRef]

Zhang, Jianhong, Haico Ebbers, and René Mulder. 2012. Competitiveness of Chinese industries-A comparison with the EU. Review of European Studies 4: 203-9. [CrossRef] 